Article

\title{
Social Investment in Aotearoa/New Zealand: Meaning and Implications
}

\section{Michael O'Brien}

School of Counselling, Human Services and Social Work, University of Auckland, Auckland 1010, New Zealand; ma.obrien@auckland.ac.nz

Received: 4 May 2020; Accepted: 24 June 2020; Published: 30 June 2020

check for updates

\begin{abstract}
Social investment has been the leit motif for the development of a range of social service provisions in Aotearoa/New Zealand for the last decade. It involves a particular approach, using data to target decisions and inform directions for such key areas as social security, care and protection of children and delivery of social services. There are serious questions about the statistical base which informs the approach and the implications for disadvantaged, marginalised and targeted populations, while poverty is neglected, sidelined and/or treated as resulting from individual failure. The Aotearoa/New Zealand model of social investment represents a significant departure from needs based, equity informed welfare provision.
\end{abstract}

Keywords: social investment; Aotearoa/New Zealand; social security; poverty; care and protection of children; social services

\section{Introduction}

Promoted by the National-led ${ }^{1}$ government, social investment has been the major political and conceptual framework for the development and delivery of social services ${ }^{2}$ (and for social service users) in Aotearoa/New Zealand (A/NZ) over the last decade. However, as Jenson (2012) notes, the specific form which social investment takes in any given jurisdiction reflects the ways in which its roots have been shaped by country specific forces. Informed and shaped by a neoliberal and conservative political framing, the $\mathrm{A} / \mathrm{NZ}$ approach to the term has been given meaning and application which is somewhat different from what has been used extensively in the international literature; of course, there are quite significant differences in the use of the term internationally.

This article begins with a description of the use and application of social investment in the A/NZ approach to social security, care and protection of children and delivery of social services. Drawing on national and international literature on social investment (with its myriad meanings), we explore issues around the implications for social security recipients, the meaning for the role/s of the state, the impact on core welfare state issues such as poverty and inequality, and some of the issues for social services and in particular for non-government organisations (ngos) delivering these services.

In brief, the New Zealand approach to social investment focuses heavily and directly on the use of government data to inform government expenditure and programmes, with that expenditure and those programmes linked to measurable outcomes. However, as indicated above, an analytic and

1 National is the conservative political party in New Zealand while Labour is the political party which developed in the early 20th century out of the trade union movement. New Zealand introduced proportional representation in 1996 and since that time has had minority and coalition governments, described in this article as 'National-led' and 'Labour-led' to indicate the major party in those coalitions.

2 While the term has a broader coverage, 'social services' are used here to refer primarily to social security and the care and protection of children. 
critical examination of the approach needs to use a wider lens in order to understand and evaluate its implications for the provision and delivery of welfare services and for the lives and position of users of those services.

This narrow, residual approach to social investment (and to welfare) stands in contrast to much of the broader social investment vision reflected in the European literature. An important distinction can be drawn between a neoliberal approach which minimises the role of the state and concentrates on expenditure within a framework of reduced citizenship rights (rather akin to the New Zealand approach) and a broader frame in which social investment is seen as contributing to a wide range of social and economic goals. While this article draws on the European approaches to social investment rather than assessing the New Zealand approach in the context of the European literature, a very brief overview of the European literature provides a useful background. Put briefly, the European work falls broadly into two approaches. The first approach is heavily influenced by and reflective of what is described as the Third Way (Giddens 1998), while a second approach includes both a critique of the Third Way and the explicit articulation of a broad alternative conceptualisation of social investment. (For a very useful overview of the European literature, see (Morel et al. 2012); Hemerijck 2017). Some elements of the Third Way approach are reflected in the New Zealand work, but the New Zealand approach is narrower than Third Way thinking. Furthermore, the broader European approach is certainly significantly more inclusive than the ideological and programmatic tone, tenor and values in the approach taken in New Zealand.

In the European literature, there is a strong emphasis on the need for a social investment strategy to include both social protection and social promotion (Morel et al. 2012), with "an investment strategy and a protection strategy constitut[ing] the indispensable twin pillars of the new welfare state" (Vandenbroucke and Vleminckx 2011, p. 451). In contrast to the narrow A/NZ approach, Van Kersbergen and Hemerijck 2012, p. 476) note that: "from a social investment perspective, welfare states are expected to help nonworking people back into employment, to complement income from employment for the working poor, to enable parents reconcile career and family life, to promote gender equality, to support child development and to provide social services for an ageing society". Or, to quote Hemerijck's more recent comprehensive review, "in essence, social investment is an encompassing strategy of developing, employing, and protecting human capital over the life course for the good of citizens, families, societies, and economies" (Hemerijck 2017, p. 19).

This is a much wider agenda and helps to highlight the importance of understanding the ways in which: "developments relating to the social investment state need to be assessed in the context of the social stratification of socio-economic outcomes" (Pintelon et al. 2013, p. 53). There is a real likelihood that the emphasis on individual responsibility and on the labour market will marginalise beneficiaries and widen inequalities (Van Kersbergen and Hemerijck 2012; Pintelon et al. 2013) because, as Rodger (2012, p. 414) notes: "the aim is not to secure the equality of living conditions but rather the participation of people in the social systems of society". As part of that participation, costs are, as Hauss (2014) notes, to be transferred from social security to paid work.

It is worth noting that the National-led government's use of social investment was not the first use of the language in A/NZ. As Lunt (2009) demonstrates, the previous Labour-led government had emphasised social development as informing its welfare work. Its approach to social development included a commitment to social protection located within an investment approach. That government, however, took a broader approach to investment than that which is discussed here, reflecting Lunt's observation that: "much of the appeal of 'social investment' lies in how the term is often used as a catch-all without fully revealing its precise meaning" (Lunt 2009, p. 9).

The Labour-led government which was in power between 1999 and 2008 had used the concept and language of investment across a range of policy initiatives "to provide a distinction ... . between good and bad public spending" (Lunt 2009, p. 8). 'Investment' is identified as good and is articulated as being in contrast to 'expenditure' which is seen as bad. The contrast is, he notes, problematic because not all government expenditure can be characterised as 'investment'; there is a critical social 
protection and social service role for government expenditure. There are, he demonstrates, two distinct uses of the term investment, namely 'investment saving' and 'investment growth' (Lunt 2009, p. 9). Furthermore, he notes, this approach to investment incorporates an emphasis on opportunities and procedural considerations rather than on outcomes. In doing so, it is akin to and builds on the neo-liberal framework which had dominated social and economic policy in A/NZ over the preceding decades.

\section{What Does Social Investment A/NZ Look Like?}

As noted above, social investment was the dominant social sector idea in the approach of the National-led government between 2009 and 2017. It has been continued, albeit with some differences, by the Labour-led government which took office in 2017 and the agency responsible for its work-initially called the Social Investment Agency-has recently been renamed as the Social Wellbeing Agency. Social investment dominated both the government's proposals and arguments, including its reforms in social security and social services. (Boston and Gill (2017) work shows that it was also being increasingly drawn on across diverse areas of government, but that is outside the scope of the focus here). For government and its working groups, social investment meant a focus on data informed, outcomes driven expenditure in which actuarial considerations would be a predominant feature. While these were not exclusive considerations - the data driven and outcome focused approach "won't be allowed to override the judgment of those tasked with delivering better results", (English 2015), the Minister of Finance (the major supporter of the social investment approach) was clear: "At its core, social investment is a more rigorous and evidence-based feedback loop linking service delivery to a better understanding of people's needs and indicators of the effectiveness of social services ... More money to invest in social services which improve people's lives in the long-term" (English 2015, unpaginated).

The Minister's deficit approach to social investment and 'the investment approach' are reflected in his argument that by identifying those at risk, the most vulnerable could be worked with 'one by one' (English 2015) to improve outcomes, reduce risk and produce improved social and fiscal results.

His views on investment and targeting were echoed by the Minister of Social Development in her approach to reforms of care and protection services: "adopting a formal investment approach that will set ambitious targets and use an actuarial model, collect evidence about what works for whom, measure the impact on outcomes including forward liability" (Tolley 2016, p. 6).

The 'actuarial valuations' to which the Ministers refers above had been a key part of the changes to social security recommended by the Welfare Working Group (2011) in a report in which social investment was the dominant and overarching rationale for reforms to the social security system. Work-focused welfare should, they argued, be based on "a long-term investment view" (Welfare Working Group 2011, p.18). 'Investment' would reduce later costs (referred to as forward liability, FWL), would enable decisions based on outcomes and formed an integral part of the underpinning core of the changes: "This reform is founded on a greater work focus for more people, reciprocal obligations, a long-term view (investing early to reduce the risk of poor long-term outcomes for many people)" (Welfare Working Group 2011, p. 18).

The work focused, investment approach to beneficiaries was accompanied by an actuarially based assessment of the long-term costs of benefit receipt and expenditure, incorporating a financial analysis of the projected changes. In turn, this led to the establishment of an Advisory Board which, using an insurance sector approach, would publish an annual actuarial based report on the future costs of social security. It was, they said, a "regularly estimated calculation of the forward liability" (Welfare Working Group 2011, p. 32) for social security benefits. This approach, the Group claimed, creates outcomes which ensure: "meeting agreed targets to reduce the forward liability and therefore reduce long-term welfare dependence" (Welfare Working Group 2011, p. 142).

The actuarially informed, data driven, investment approach also informed changes to care and protection services for children and young people. The new system was defined as "a cross sector 
social investment system" (Modernising Child Youth and Family Expert Panel ${ }^{4}$ 2015b, p. 10): in which forward liability (the cumulative costs across a lifetime) points to the significant fiscal and social benefits of intervening as soon as possible, when problems are less entrenched and damaging (Modernising Child Youth and Family Expert Panel 2015b, p. 10).

The Panel's report went on to argue that an actuarial valuation of long-term costs arising from poor outcomes sat at the centre of its investment approach to changes to government care and protection services. The Panel was chaired by Paula Rebstock who had also chaired the WWG. "An investment approach for vulnerable children will underpin the transformation of the system from one that is incident-oriented and focused on short-term safety and offending, to one that fundamentally considers a lifetime view of the well-being of individual children, and intervenes early to address the factors contributing to child vulnerability and the costs associated with poor outcomes" (Modernising Child Youth and Family Expert Panel 2015b, p. 63).

In addition to its usage as an overarching framework in these two reviews, 'investment' is also used by the Expert Panel to refer to the development of government structures, with reference, for example, to a Social Investment Board and is used to argue the case for expenditure in different areas of support and services for children and families. Its significance is perhaps reflected in the use of the word 'investment' in the titles for two of the ten chapters in the Panel's final report- 'Case for Investment' and 'Investing in the Future' - and was identified as one of the six building blocks for the new agency (Modernising Child Youth and Family Expert Panel 2015b). The recommended new Department was described as a 'social investment department' ${ }^{5}$ (Modernising Child Youth and Family Expert Panel 2015b, p. 14). Inter alia, the Panel's terms of reference included "the development of an investment approach for Child, Youth and Family to ensure spending is focused on results" and "the potential role of data analytics, including predictive risk modelling, to identify children and young people in need of care and protection" (Modernising Child Youth and Family Expert Panel 2015b, p. 242).

The reference here to predictive risk modelling (PRM) requires some brief comment. Using administrative data, (PRM) was developed and promoted by Vaithianathan and her colleagues as a tool for identifying children's risk of abuse, providing a basis and rationale for state action to protect those children identified as being at high risk. The authors argued that the tool would "automatically generate a risk score for children either (1) when they arrive on the benefit system or (2) when their circumstances change once supported by a benefit" (Vaithianathan et al. 2012, p. 6). Those whose score exceeded a particular threshold would then be identified as at risk of possible maltreatment. The paper identifies a range of ethical issues associated with the use of the approach but argues that these can be managed and it (the report) goes on to suggest that the approach could be widened to include children who are not in a household receiving a benefit.

Ethical issues include considerations of privacy and autonomy, confidentiality and relationships between service users and service providers. They extend too to considerations of possible stigma for those who are identified as 'needing intervention', given the difficulties in using the data to identify those 'at risk' and the broad range of considerations surrounding effective intervention. Here, core issues of identification of those at risk arise because some of those statistically identified as 'at risk' will not be harmed and their parents/carers will not be responsible for causing harm. (For a thorough and thoughtful discussion on these and related issues, see Keddel 2014).

The investment framed, outcomes focused, data driven approach was also applied and utilised throughout the broader social service changes the government developed, reflected, inter alia, in the titles of three key documents from the Ministry of Social Development, Investing in Services

4 The full title is Modernising Child Youth and Family Expert Panel; this title is used in the references but is shortened here for ease of reading.

5 The government created the Ministry of Vulnerable Children, a term that was widely rejected by those working in the field. Subsequently the Labour-led government changed the name to Oranga Tamariki (Ministry for Children), literally translated as the wellbeing of children. 
for Outcomes (ISO), Strategic Investment Framework (SIF) and Community Investment Strategy (CIS) (Ministry of Social Development 2015). In these documents, investment framing is used to argue for and develop changes in the support for and funding of social services, with investment in outcomes to be used as the basis for that funding. The changes are quite explicitly linked to government defined priorities.

The SIF and the Investment strategy would, it said, "connect funding decisions with government priorities and areas of greatest community need" and "give providers more certainty to enable them to invest in the right areas" (Ministry of Social Development n.d.a); providers would be linked into the strategy and language of investment and into government priorities. Importantly, subsequent documents only refer to government priorities, and drop the reference to 'areas of greatest community need'. ISO contains two key components, the Strategic Investment Framework and an Investment Strategy. These have two major purposes and foci, reflected in the statement in the SIF that the framework will guide decisions by "defining the outcomes the Ministry wants to see and how the services we fund will help achieve these outcomes" (Ministry of Social Development n.d.b).

In both its title and its initial statement,- “The Ministry of Social Development wants to achieve better outcomes through more effective engagement with community service providers" (Ministry of Social Development n.d.a)-ISO is clearly emphasising the significance of outcomes but note that the reference here is not to outcomes as measured through data but through relationships with providers. Moreover, the investment approach would shape the work of social service providers through, as noted above, investing 'in the right areas'. Providers become linked into the strategy and language of investment and closely linked to government priorities.

It was anticipated that all social service contracts would have outcomes focused performance measures, and "unnecessary duplication will be removed" (Ministry of Social Development 2015, p. 7). This claim echoed the statement in the SIF document from the Ministry which argued that the investment framework would allow the Ministry to make decisions about what outcomes, groups and locations would be prioritised and what services would be purchased. As is reflected elsewhere in this article, contracts would be data informed in order to identify ways in which spending could be linked to outcomes.

The social services were also the focus of one of the early pieces of work by the productivity Commission, an independent Crown entity ${ }^{6}$. Acting on terms of reference given to it by the Minister of Finance, the Commission incorporated the language and framework, and many of the related elements, of 'social investment' into its review of the social services. The Commission produced three documents on the social services in 2014 and 2015 (The New Zealand Productivity Commission 2014; Mansell 2015; The New Zealand Productivity Commission 2015). While the Commission uses 'social investment', this is clearly in an insurance context-the two are linked together in heading a section of the report (The New Zealand Productivity Commission 2015) and the discussion on the investment approach sits alongside a discussion of social insurance. However, while supporting both the idea of the social investment approach and its wider application and use, the Commission argued for a family of investment approaches and a more devolved model of social investment for the social services. The Commission also observed that the focus on reducing welfare rolls is too narrow (The New Zealand Productivity Commission 2015, p. 226).

The Institute of Economic Research, one of the few commentators on the A/NZ social investment approach, argued that the approach had something to offer in the provision and delivery of social programmes. It was, they said: "an interesting idea with considerable promise" (New Zealand Institute of Economic Research 2016a, p. 38). The approach would, they claimed, refine the welfare state so that it dealt with specific needs and, reflecting the insurance language, lead to a focus on specific

6 An 'independent Crown entity' is generally independent of government policy and has a quasi-judicial function or duty to monitor, review, mediate or investigate. 
risks. This would, they argued "increase the sophistication of the welfare state" (Op. cit., 15). In a later document, they went on to argue that a successful social investment approach would lead to a country which would be free of "sustained cycles of disadvantage, with higher rates of social mobility, improved life-chances and greater wellbeing" (New Zealand Institute of Economic Research 2016a, p. 2).

While the New Zealand emphasis on data informed outcomes as the basis for its social investment approach to social security and social services (including particularly care and protection of children) has some quite distinctive elements when compared with the broader approach adopted in much of the international work on social investment (see above), the approach raises important questions and issues for discussion. First, how robust is the approach to and use of the statistical data? Second, and in part associated with the third question below, what are the implications of the A/NZ social investment framework for approaches to and reduction of poverty, a central task, as Hemerijck (2017) notes, of state welfare provision? Third, what are the implications of the emphasis for the role of the state, particularly in relation to the provision and delivery of social services? It is those questions to which we now turn.

\section{Statistical Issues}

Focusing in part on statistical and methodological issues arising from the use of official data, Chapple (2013) is quite critical of the design of social investment. He describes FWL, one of the core elements for measuring the effectiveness of social investment, as "neither a relevant nor reliable indicator" and as not being "carefully unpicked" and is, he argues, "at best ... . no more than an expensive and partial cul-de-sac" (Chapple 2013, p. 62). His general commentary on the methodology and its application is given some specific weight by Treasury (2016a) in its analysis of data drawn from the Integrated Data Infrastructure (IDI), the administrative framework gathering information from a range of government agencies.

Drawing on the data available for a cohort, born in 1993 enrolled in school in 2008-2009, and those aged 0-14 at 31 December 2013, the Treasury work leads to three important questions about the relationship for a group of children between the risk factors ${ }^{7}$ identified and the outcomes linked with those risk factors. First, there is a risk of causation and correlation becoming confused. Second, there is a risk of false positives and false negatives arising from the jagged link between risk and outcome; that is, some of those with low risk have poor outcomes while some of those with high risk do not have poor outcomes. Third, they note that the risk factors may be masking underlying patterns of poverty and deprivation. The geographical maps included in their work suggest that there is merit in this argument and that the areas in New Zealand with high levels of risk (as reflected in the deprivation index ${ }^{8}$ ) also show high levels of deprivation. For example, the map of Auckland showing high levels of risk in the Auckland region corresponds strongly with areas in Auckland where there is high level of poverty and deprivation (Treasury 2016b). In a general sense, the Treasury Infogram (Treasury 2016a) demonstrates that the relationship between the risk factors and the outcomes is what can only be described as being at best tenuous (author's description, not theirs). For example, focusing on those with two or more of the four risk factors identified, the Treasury Infogram (Treasury 2016a) notes that:

- 121,400 children have two or more of the key risk indicators and poor outcomes

- one-third of children $(42,500)$ with two or more of the key risk indicators do not have poor outcomes

- the majority of children who have a poor outcome have no or one risk indicator

- of those with two or more risk indicators, 63\% are Māori, 12\% are Pasifika, 23\% are Pakeha.

7 The four risk factors are a finding of abuse or neglect, mostly supported by benefits since birth, parent with a prison or community sentence, mother with no formal qualification.

8 For further discussion on deprivation indices in A/NZ see Atkinson et al. (2019). 
Similar and related issues were identified in the use and application of the PRM tool (outlined briefly above) for measuring the risk of child abuse, a tool that, as noted above, was also based on sets of indicators. As Campbell (2015) spells out, the assessment of risk led to false positives and a range of statistical and ethical issues arising from the application of the tool. Campbell identifies a range of weaknesses, namely the risk of false positives, privacy issues, confusion between causation and correlation (an issue identified above in the Treasury work) and: "the creation of a tier of beneficiary families whose rights are treated as secondary to those of other citizens and the risk of further stigmatising communities and racial groups already suffering from the marginalising effects of poverty" (Campbell 2015, unpaginated).

He goes on to argue that there are significant risks with PRM in applying it to the practice of social work, but, more significantly, argues that it is consistent with the development of a residual form of welfare in which the emphasis is on minimal state provision rather than on providing comprehensive universal services. PRM will, he argues, provide a mechanistic way to provide services and act as a route to privatisation of social services. His conclusion is direct and telling: "the evidence is that in its current form, the PRM tool will do more harm than good to the complex, often abrasive tasks of social casework practice." (Op. cit.)

\section{Providing and Delivering Welfare}

In addition to, and, arguably much more significant than, the statistical issues, the particular form of social investment in A/NZ and its articulation has critical implications for the direction and development of welfare in this country. Here, I am in part reflecting Dowling and Harvie (2014) argument that the social investment approach carries important questions about how welfare is to be provided and delivered, the basis of that provision and the consequences thereof. Inter alia, welfare would become more tightly targeted, with an emphasis on individual and familial responsibility through the market place, a correspondingly reduced state responsibility, weakening of citizenship rights, exclusion rather than inclusion, greater state oversight, surveillance and control and individualised responses to poverty. These and related issues are, then, the focus of attention for the remainder of this article. The issues are necessarily and inevitably interrelated making a simple linear discussion impossible. Targeting and the role of the state provide a framework around which to structure the discussion. Of course, they too are interconnected!!

It is a discussion which is much narrower than the more general discussion in the literature about the relationship between the social investment state and neoliberalism. (For a useful approach to this more general discussion, see Tickell and Peck 2003; Larner et al. 2007; Simon-Kumar 2011). Rather, as indicated above, the issues of interest here revolve around a range of central considerations in welfare provision emanating from a statistically shaped and data informed social investment formally designed to achieve effective outcomes. To reiterate, social investment A/NZ style contained a number of inter-related themes, namely 'productive investment' based on measured and identified successful outcomes (with success largely measured by reduced public expenditure), targeting of expenditure on those who reflect those outcomes, an emphasis on individual and familial responsibility for income support with that responsibility reflected in and through participation in the paid labour market. The vision is, as Rodger observes: "a society populated by enterprising and educated citizens who are responsible for themselves and their families and eager to engage in productive work" (Rodger 2012, p. 414).

As noted in the earlier discussion in this article, the strong emphasis on outcomes based targeting requires and is built on identifying those failing and failed individuals ('one by one') whose lives can be improved because that will reduce future government expenditure (FWL) and is an efficient use of government resources. Individualisation, as Berthet and Bourgeois (2014, p. 28) note: "relies on defining the vulnerable populations on which to focus and tailor-make services". Targeting in this context becomes possible because the data driven approach enables identification of those individuals and groups where there have been successful outcomes and, by implication, identification of those 
on whom there should not be expenditure because of the lack of successful outcomes. Of course, as the Minister of Finance noted, algorithms are not the sole determinant of resource allocation. Nevertheless, their dominant role is clear and there are critical ideological and political messages arising from the emphasis on successful outcomes. It is this group which, as Hauss (2014, p. 657) noted, "yield returns".

The A/NZ emphasis on paid work and activation, accompanied by increased obligations and sanctions for those who failed to meet the requirements, was firmly located in the language and ideology of social investment. Social investment served as an ideological, discursive and political legitimiser. A core part of this approach is the emphasis on individual responsibility, on the labour market and the family (discussed further below) and on a reduction in state provision. As indicated above, it is a residual approach to welfare provision, with participation in the labour market defined and operationalised as the primary route to economic support. The welfare state becomes rebuilt around work, with work defined as paid work and unpaid caring work (discussed more fully below) omitted from the discussion.

While A/NZ emphasises what the Minister described as 'an unrelenting focus on work' (Bennett 2010), much of the European literature draws a distinction between social investment and activation. Hauss (2014, p. 658), for example, argues, in contrast to the A/NZ approach, that: "social investment cannot be equated with workfare". While social investment in A/NZ is based on the potential of future returns, particularly through participation in the labour market, welfare provides support based on some test of need and circumstances and this rather than 'future returns on investment' determine eligibility for assistance.

Weaved through this discussion, both explicitly and implicitly, is a critical theme around the ways in which the A/NZ approach to social investment incorporates, requires and emphasises the responsibilities of citizens, and the concomitant reduction of their rights. An integral part of the social investment approach to social security, as set out by the WWG and legislated by the National-led government, is the range of obligations placed on beneficiaries, particularly in relation to work availability and preparation for participation in paid work. These obligations are accompanied by sanctions imposed for failure to comply with them.

Hauss (2014, p. 657) captures the meaning of this approach neatly: "investment based social policy requires beneficiaries to provide a service in return, since only activated persons are deemed worthy of investment". It is these persons who are to be worked with 'one by one'. While supports remain in place for those who cannot be activated, resources for those identified as being likely to have a successful outcome are prioritised. This emphasis on individual responsibility and the associated limits in relation to access to welfare benefits will, as Pintelon et al. (2013) note, generate new forms of marginalisation. Society becomes divided between insiders and outsiders with increased likelihood of various forms of social exclusion. Those for whom investment 'fails' are poor risks and consequently run the risk of being excluded. In a comparable vein, the Modernising Child Youth and Family Expert Panel (Modernising Child Youth and Family Expert Panel 2015a, 2015b) approach designated children needing care and protection services as 'vulnerable' and in that sense distinct from 'other' children.

Interestingly, Lunt (2009) had observed elements of this approach in his earlier work on the Labour-led government's emphasis on social development, because, he argued, the focus there was on what was called 'the opportunity society' and lacked what he called "a robust notion of inclusion" (Lunt 2009, p. 10) because of the ways in which individual achievement had been highlighted. This resulted from the conflation of opportunity and responsibility and, he argued, those who failed only had themselves to blame.

This process of identifying and concentrating resources on those who are most likely to have successful outcomes has one other important consequence, a consequence that is inherent in the process. There is what Hauss (2014) describes as a creaming effect; those with the best prospects are selected for intervention while "left behind are persons with poor prospects" (Hauss 2014, p. 667). 
Gray (2019) notes this in her work with agencies engaged with young people who are subject to money management.

While the major emphasis through this discussion has been on the social investment informed social security changes, the emphasis on state oversight and investment to reduce future expenditure and create future citizens also informed the changes to the care and protection of children. It is an approach which, as Keddel (2017) notes, conflates investment and prevention of child abuse and neglect. As with the approach to social investment embedded in the social security changes, social investment in care and protection is also firmly located, inter alia, in future liability. (For a more extensive discussion of these issues, see Hyslop 2017).

The emphasis on individual and family responsibility, and on the associated reduction in state provision, and on work as the determinant of social security does not mean a diminished state. The state is, as Rodger (2012, p. 428) notes: "liberal at the top but punitive and interventionist at the bottom". Implicit, and indeed explicit at times in this discussion, is the notion of the surveillance role of the state and its role in overseeing, managing, supervising, steering and directing citizens. Gray (2014) takes this up in relation to the development of policies around families, including social work with families, referring to "the key focus on "investing in children" and developing "responsible parents", noting that this has important implications for social work practice; it should be noted that there are, of course, important neoliberal government components embedded within this approach.

She goes on to argue that: "many have shown how social work with families, rather than providing assistance to those in need or at risk, does little more than investigate, assess and subject families to punitive monitoring and surveillance" (Op. cit., 1763). Social work is she argues: "being marginalised in areas of remedial action and implementing conditional and punitive welfare"... (Op. cit., 1764).

Citizenship rights, an inherent part of the development of the welfare state (Dwyer 2004), are significantly weakened in the A/NZ social investment state. Benefits become conditional, duties are highlighted and individual responsibilities are reinforced. Significantly, wider considerations of equity were discarded because, the actuarial report said, costs could not be easily allocated and "therefore in this context [equity] is considered of minor importance" (Taylor Fry 2011, p. 11). Reflecting and reinforcing the WWG's prioritising of paid work, they argued that "welfare is a system of last resort" (Taylor Fry 2011, p. 16. (For a critical discussion of the implications of the work of the WWG for citizenship rights, see O’Brien 2015).

\section{Reducing Poverty}

One of the other critical questions arising from the A/NZ social investment emphasis and approach is the implications for inequality and poverty, issues which have been central to social welfare programmes and policies, historically and internationally. Since paid work, and, therefore, participation in the labour market, is the focus of the social investment informed social security system, it (the labour market), not the state, becomes the institution which generates income and, by definition, the institution which will respond to and manage poverty. While the WWG's terms of reference excluded attention to benefit levels and benefit adequacy, neither the discussion documents nor the final report undertook any analysis of the implications of the emphasis on paid work for issues of poverty or on the implications of their proposals for poverty rates. These rates were already quite high, with more than $20 \%$ of children below the $60 \%$ median income poverty line (Perry 2014).

In their approach, with its emphasis on the responsibilities of individuals and families, poverty is regarded as an individual failing and defect rather than stemming from economic and social structures. Moreover, the emphasis on the duties and obligations of beneficiaries, without any duty on the state to ensure income adequacy and without any obligation for the state to protect the rights of beneficiaries, reinforces the ideological and discursive message that poverty is an individual failing. It is the reverse of Cantillon (2011, p. 445) requirement for an effective investment strategy which includes: "adequate social security and efficient social redistribution", a requirement noted in much of the international literature and many of the debates on social investment (Esping-Andersen et al. 2002; Hemerijck 2017). 
In her view, the emphasis on activation and investment (rather than social protection) is an important factor in poverty trends; while it is too early to identify if this will also happen in A/NZ, it is worth noting that there has been no improvement in poverty levels over the last decade, with the beneficiary population heavily over-represented in poverty numbers (Perry 2019). At an international level, Nygard and Krugar (2012) make a similar point, describing the residual social investment state as 'ameliorative rather than redistributive', with limited attention to poverty reduction. The creation and strengthening of beneficiary obligations and the associated sanctions discussed above will create new forms of marginalisation for beneficiaries, reinforcing the exclusion and othering of beneficiaries who face requirements not placed on other citizens, including those in work who receive assistance from the state. For example, the social security legislative changes following the WWG report require beneficiaries to have health checks for their children and enrol them in early childhood education, requirements not faced by those families in paid work receiving state assistance through tax credits. The emphasis on FWL and the future costs of social security mean that the focus is on removing people from the welfare roll into paid work, without attention to the nature and permanence of that work. As observed above, Campbell (2015) highlights this also in his discussion of PRM. Recent research shows that many of those who were removed from the welfare rolls returned to welfare within quite a short time (Judd and Gibbs 2020). None of this is surprising because the reforms were focused on moving people from benefit into work and showed no interest in the nature, security and quality of that work. Moreover, as noted in this article, the reforms were not interested in poverty reduction, with the terms of reference for the WWG explicitly excluding benefit rates from those terms of reference.

The lack of attention to the significance of poverty is replicated in the social investment framing of the care and protection of children. While poverty is mentioned in passing as one of the considerations influencing child neglect and abuse (Modernising Child Youth and Family Expert Panel 2015b), the reference to its significance is not taken up at all in the subsequent discussions on changes to care and protection of children. Rather, poverty is listed as one of a number of indicators of vulnerability and the response is on an individualised basis in terms of referral to a helping service. In the interim report (Modernising Child Youth and Family Expert Panel 2015a, p. 38), poverty is identified as a possible factor (among many others) which might be linked to poor outcomes for children and young people.

'Poor outcomes' are identified as youth justice referral, no Level $2 \mathrm{NCEA}^{9}$, being in receipt of a benefit, or being on a benefit or on a benefit with a child before 21, a custodial or community sentence before 21 (Modernising Child Youth and Family Expert Panel 2015a, p. 38, Figure 4.4). The social structures which produce these 'poor outcomes' are ignored; emphasis is placed on dealing with the children at an individual level, in much the same way as the response to beneficiary poverty is individualised. The extensive evidence about the significance of poverty in relation to child neglect and abuse (Pelton 2015; Bywaters et al. 2017) is neglected.

While the focus here is on the care and protection of children, Cantillon (2011, p. 445) observation that: "living at-risk-of-poverty remains a handicap for achieving success at school, in the workplace and within family life" is very apt for the social investment approach to both social security changes and changes in the care and protection of children. However, as she notes social investment and the investment state are not a replacement for redistributive efforts to reduce poverty; to reiterate, an effective investment strategy needs to include both social redistribution and adequate social security.

A further point to note here is that the very heavy emphasis on employment and activation which characterises the A/NZ social investment approach both directly and indirectly downplays the significance of caring (referred to earlier), whether that is parental care for children or other components of care. In the approach to children and child care in both policy areas reviewed here, the focus on women is on their participation in the labour market. As noted above, work is defined as paid work

9 NCEA is the national secondary school qualification; it is an abbreviation for National Certificate of Education Achievement and has three levels. Students enrol in it in their final three years of secondary schooling. 
and the work of caring is at best downplayed and at worst disqualified. Caring work is devalued alongside and set in contrast to the paid labour market. It is neglected because social investment locates the active citizen in the labour market. The focus is on: "investing in children and families to make them productive contributors to society" (Gray 2014, p. 1753), and the importance of caring for children is devalued. The emphasis is placed on what children are to become, not their current state of being (Lister 2003).

A final brief reflection-what do these changes mean for the provision and delivery of social services? As noted above, the range of documents from the Ministry of Social Development set out a framework for the social services that was reflective of and informed by the social investment framework. Concrete changes resulting from this have been, at times, difficult to identify but the Minister of Social Development and the Minister of Finance were both clear that services would be funded on the basis of successfully meeting outcomes (Bennett 2012).

Two important observations are worth making here. First, research on the impacts of money management by non government organisations contracted to the Ministry of Social Development (MSD) indicates that achieving successful outcomes shaped the services from those organisations (with important implications for deciding to whom services would be provided) (Moore 2019). Second, and implicit in this development, increasingly the work of many of those organisations becomes shaped by the government contracts, with government determining what the agencies will provide, rather than the agencies determining services based on their assessment of need (O'Brien et al. 2009). The focus becomes the terms of contract (Milbourne and Cushman 2015, p. 17) and government increasingly moves "into previously autonomous domains of civil society". Increasingly there is the risk that it is government goals that determine the nature and terms of the contract, not the needs of individuals, families and communities.

Where to from here? As noted above, subsequent to its election in 2017, the Labour-led government changed the name of the Social Investment Agency to the Social Wellbeing Agency in 2020. 'Wellbeing' has become a central political and discursive term for this government, with the word being used as part of the annual government budget process. The Budget document is entitled 'The Wellbeing Budget'. The Agency defines wellbeing as enabling "people, whānau and communities to live the lives they aspire to, including both material conditions and quality of life. A social wellbeing approach is centred on people, with an emphasis on broad measures of wellbeing" (Social Wellbeing Agency 2020). It (the agency) still has a strong focus on the use of official government data to inform and guide decision making and describes its work as partnering "with the social sector, combining science, data and lived experience to draw insights that are enriched by whānau voices" (Social Wellbeing Agency 2020). While this is a wider frame than that adopted by the previous government, a detailed analysis of its work and approach (and assessment of changes in direction, if any) lies ahead.

\section{Conclusions}

The A/NZ approach to social investment reflects and represents a marked shift in direction for the provision of welfare services and programmes. The emphasis on a data driven approach to interventions and services reflects a highly targeted, individualised welfare programme in which services and interventions would be based not on need but on statistically informed, actuarially driven assessment of the outcomes of intervention, with assistance designed to reduce future costs to the state. It is an approach in which the structural considerations underlying disadvantage, inequality and poverty are denied and pushed aside. Service users will become increasingly excluded and marginalised as their lives are, increasingly, closely overseen and subject to particular behavioural requirements and close surveillance. Changes in direction will require building an understanding of the ways in which the daily lives and experiences of the most disadvantaged citizens are shaped and blighted by the range of structural inequalities which have, historically, been central to provision of comprehensive state welfare services. Those services need to change but social investment as 
developed in Aotearoa/New Zealand moves down the opposite route to that required to travel towards a fairer and better society.

Funding: This research received no external funding.

Conflicts of Interest: The author declares no conflicts of interest.

\section{References}

Atkinson, June, Clare Salmond, and Peter Crampton. 2019. NZDep2018 Index of Deprivation. Dunedin: Department of Public Health, University of Otago.

Bennett, Paula. 2010. Future Focus. Wellington: Minister of Social Development.

Bennett, Paula. 2012. Address to New Zealand Council of Christian Social Services. Available online: www. parliament.nz (accessed on 12 December 2012).

Berthet, Thierry, and Clara Bourgeois. 2014. Towards 'activation friendly' integration? Assessing the progress of activation policies in six/European Countries. International Journal of Social Welfare S 23: 23-39. [CrossRef]

Boston, Jonathan, and Derek Gill, eds. 2017. Social Investment. A New Zealand Policy Experiment. Wellington: Bridget Williams Books.

Bywaters, Paul, Geraldine Brady, Lisa Bunting, Brigid Daniel, Brid Featherstone, Chantel Jones, Kate Morris, Jonathan Scourfield, Tim Sparks, and Calum Webb. 2017. Inequalities in English child protection practice under austerity: A universal challenge? Child \& Family Social Work 23: 53-61.

Campbell, Gordon. 2015. Is Big Data Really Able to Predict Child Abuse? Werewolf, September 23.

Cantillon, Bea. 2011. The paradox of the social investment state: growth, employment and poverty in the Lisbon era. Journal of European Social Policy 21: 432-49. [CrossRef]

Chapple, Simon. 2013. Forward Liability and Welfare Reform. New Zealand Policy Quarterly 9: 55-62.

Dowling, Emma, and David Harvie. 2014. Harnessing the Social: State, Crisis and (Big) Society. Sociology 48: 869-86. [CrossRef]

Dwyer, Peter. 2004. Understanding Social Citizenship. Bristol: Policy Press.

English, Bill. 2015. Speech to the Treasury Guest Lecture Series on Social Investment; September 15. Available online: www.treasury.govt.nz (accessed on 12 December 2015).

Esping-Andersen, Gosta, Duncan Gallie, Anton Hemerijck, and John Myles. 2002. Why We Need a New Welfare State. Oxford: Oxford University Press.

Giddens, Anthony. 1998. The Third Way: The Renewal of Social Democracy. Malden: Polity Press.

Gray, Mel. 2014. The Swing to Early Intervention and Prevention and its Implications for Social Work. British Journal of Social Work 44: 1750-69. [CrossRef]

Gray, Claire. 2019. The implementation and impact of National's welfare conditionality in an international context. New Zealand Sociology 34: 71-92.

Hauss, Gisela. 2014. Generating productive citizens or supporting the weak? Ambivalences and contradictions in working with young welfare recipients. European Journal of Social Work 17: 656-71. [CrossRef]

Hemerijck, Anton, ed. 2017. Social Investment and Its Critics. In The Uses of Social Investment. Oxford: Oxford University Press, pp. 3-40.

Hyslop, Ian. 2017. Child Protection in New Zealand: A History of the Future. British Journal of Social Work 47: 1800-17. [CrossRef]

Jenson, Jane. 2012. Redesigning citizenship regimes after neoliberalism: Moving towards social investment. In Towards a Social Investment State? Ideas, Policies and Challenges. Edited by Nathalie Morel, Bruno Palier and Joakim Palme. Bristol: Policy Pres, pp. 61-87.

Judd, Eric, and John Gibbs. 2020. What Happened to People Who Left the Benefit System during the Year Ended June 30, 2016. Wellington: Ministry of Social Development.

Keddel, Emily. 2014. The ethics of predictive risk modelling in the Aotearoa/New Zealand child welfare context: Child abuse prevention or neo-liberal tool? Critical Social Policy. Critical Social Policy. [CrossRef]

Keddel, Emily. 2017. The Child Youth and Family Review: A Commentary on Prevention. Auckland: Auckland University of Technology. 
Larner, Wendy, Richard Le Heron, and Nicholas Lewis. 2007. Co-constituting 'After Neoliberalism': Political Projects and Globalizing Governmentalities in Aotearoa/New Zealand. In Neoliberalization: States, Networks, Peoples. Edited by Kim England and Kevin Ward. Oxford: Blackwell Publishing, pp. 223-47.

Lister, Ruth. 2003. Investing in the Citizen-Workers of the Future: Transformations in Citizenship and the State under New Labour. Social Policy and Administration 37: 427-43. [CrossRef]

Lunt, Neil. 2009. The rise of a 'social development' agenda in New Zealand. International Journal of Social Welfare 18: 3-12. [CrossRef]

Mansell, James. 2015. Handing Back the Social Commons. Wellington: New Zealand Productivity Commission.

Milbourne, Linda, and Mike Cushman. 2015. Complying, Transforming or Resisting in the New Austerity? Realigning Social Welfare and Independent Action among English Voluntary Organisations. British Journal of Social Policy 44: 463-85. [CrossRef]

Ministry of Social Development. 2015. Community Investment Strategy. Available online: http://www.msd.govt.nz (accessed on 23 November 2015).

Ministry of Social Development. n.d.a. Investing in Services for Outcomes. Available online: http://www.msd. govt.nz (accessed on 23 November 2015).

Ministry of Social Development. n.d.b. Strategic Investment Framework. Available online: http://www.msd.govt. nz (accessed on 23 November 2015).

Modernising Child Youth and Family Expert Panel. 2015a. Expert Panel Interim Report. Available online: www.msd.govt.nz (accessed on 23 November 2015).

Modernising Child Youth and Family Expert Panel. 2015b. Expert Panel Final Report. Investing in New Zealand's Children and Their Families. Available online: www.msd.govt.nz (accessed on 23 November 2015).

Moore, Charlotte. 2019. What works? Social investment, big data and social services in Aoteaora/New Zealand. New Zealand Sociology 34: 123-47.

Morel, Nathalie, Bruno Palier, and Joakim Palme, eds. 2012. Towards a Social Investment State? Ideas, Policies and Challenges. Bristol: Policy Press.

New Zealand Institute of Economic Research. 2016b. Defining Social Investment, Kiwi Style. Working Paper 2016/5. Wellington: New Zealand Institute of Economic Research.

New Zealand Institute of Economic Research. 2016b. Social Investment-New Right Agenda or New Wine in Old Bottles? NZIER Insight 67/2016. Wellington: New Zealand Institute of Economic Research.

Nygard, Mikael, and Nicole Krugar. 2012. Poverty, Families and the Investment State. European Societies 14: 755-77. [CrossRef]

O'Brien, Michael. 2015. Inclusion, Citizenship, Poverty and Welfare Reform. In Inclusive Growth, Development and Welfare Policy. A Critical Assessment. Edited by Reza Hasmath. New York: Routledge, pp. 195-210.

O'Brien, Michael, Jackie Sanders, and Margaret Tennant. 2009. The New Zealand Non-Profit Sector and Government Policy. Wellington: Office for the Community and Voluntary Sector.

Pelton, Leroy. 2015. The continuing role of material factors in child maltreatment. Child Abuse and Neglect 41: 30-39. [CrossRef] [PubMed]

Perry, Bryan. 2014. Household Incomes in New Zealand: Trends in Indicators of Inequality and Hardship 1982 to 2018. Wellington: Ministry of Social Development.

Perry, Bryan. 2019. Household Incomes in New Zealand: Trends in Indicators of Inequality and Hardship 1982 to 2013. Wellington: Ministry of Social Development.

Pintelon, Olivier, Bea Cantillon, Karel Van den Bosch, and Christopher Whelan. 2013. The social stratification of social risks: the relevance of class for social investment strategies. Journal of European Social Policy 23: 52-67. [CrossRef]

Rodger, John. 2012. 'Regulating the Poor': Observations on the Structural Coupling of Welfare, Criminal Justice and the Voluntary Sector in a 'Big Society'. Social Policy and Administration 46: 313-431. [CrossRef]

Simon-Kumar, Rachel. 2011. The Analytics of "Gendering" the Post Neo-liberal State. Social Politics 18: 411-68. [CrossRef]

Social Wellbeing Agency. 2020. What We Do. Available online: www.swa.govt.nz (accessed on 16 June 2020).

Taylor Fry. 2011. Actuarial Advice of Feasibility: A Long-Term Investment Approach to Improving Employment, Social and Financial Outcomes from Welfare Benefits and Services. Available online: www.taylorfry.com.au (accessed on 30 June 2020). 
The New Zealand Productivity Commission. 2014. More Effective Social Services. Issues Paper. Wellington: Productivity Commission.

The New Zealand Productivity Commission. 2015. More Effective Social Services. Wellington: Productivity Commission.

Tickell, Adam, and Jamie Peck. 2003. Making Global Rules: Globalization or Neoliberalization? In Remaking the Global Economy. Edited by Jamie Peck and Henry Wai-Chung Yeung. London: Sage, pp. 163-81.

Tolley, Ann. 2016. Investing in New Zealand's Children and Their Families. Overview-Final Report of the Modernising CYF Expert Panel: Proposed Blueprint for Reform and Implementation. Wellington: Cabinet Social Policy Committee.

Treasury. 2016a. Characteristics of Children at Risk. Available online: www.treasury.govt.nz (accessed on 24 November 2016).

Treasury. 2016b. Characteristics of Children at Risk. A Regional Picture of Children at Higher Risk. Available online: www.treasury.govt.nz (accessed on 24 November 2016).

Vaithianathan, Rhema, Tim Maloney, Nan Jiang, Irene De Haan, Claire Dale, Tim Dare, and Emily Putnam-Horstein. 2012. Vulnerable Children. Can Administrative Data Be Used to Identify Children at Risk of Adverse Outcomes? Auckland: Centre for Applied Research in Economics, University of Auckland.

Van Kersbergen, Kees, and Anton Hemerijck. 2012. Two Decades of Change in Europe: The Emergence of the Social Investment State. Journal of Social Policy 41: 475-92. [CrossRef]

Vandenbroucke, Frank, and Koen Vleminckx. 2011. Disappointing social poverty trends: Is social investment to blame? Journal of European Social Policy 21: 450-71. [CrossRef]

Welfare Working Group. 2011. Reducing Long-Term Benefit Dependency. Available online: www.ips.vuw.ac.nz (accessed on 23 February 2011).

(C) 2020 by the author. Licensee MDPI, Basel, Switzerland. This article is an open access article distributed under the terms and conditions of the Creative Commons Attribution (CC BY) license (http://creativecommons.org/licenses/by/4.0/). 